\title{
Temporal niche overlap and distinct bee ability to collect floral resources on three species of Brazilian Malpighiaceae
}

\author{
Gudryan Jackson BARÔNIO ${ }^{1,2}$, Helena Maura ToREZAN-SILINGARDI ${ }^{2}$ \\ ${ }^{1}$ Programa de Pós-Graduação em Ecologia e Conservação de Recursos Naturais, Uberlândia, Brazil \\ ${ }^{2}$ Instituto de Biologia, Universidade Federal de Uberlândia, Campus Umuarama, R: Ceará, S/N, Bloco 2D, CEP, \\ Uberlândia, Minas Gerais 38400-902, Brazil
}

Received 14 December 2015 - Revised 25 April 2016 - Accepted 13 July 2016

\begin{abstract}
Spatial and temporal limited resource and niche overlap studies have been widely used to explain resource-sharing in community ecology. Furthermore, morphological and behavioral differences among species are relevant to predict how they may share niche availabilities. We evaluated temporal niche overlap and the ability of visitors to collect floral resources on three Malpighiaceae species in the Brazilian savannah. We hypothesized: (I) an overlap between the temporal niches due the similarities between their floral resources requirements and the temporal limitation of flowering; and (II) a differential ability of bee species in resource harvesting. The 31 floral visitor species exhibited a higher niche overlap than expected by chance, confirming our first hypothesis. Furthermore, according to our second hypothesis, we observed that floral visitors showed a different efficiency in resource collection, depending on bee size and behavior. We believe that this may be a proxy of pollination efficiency. Our discussion is based on the distinct specialization of oil-collecting abilities and the specific requirements of each bee tribe.
\end{abstract}

\section{Centridini / environmental conditions / oil-collecting bees / pollinator efficiency / sequential flowering}

\section{INTRODUCTION}

Studies related to floral visitor niche overlap have been widely used to explain the distribution and use of natural resources by different species that make up the community (Santos et al. 2013), since resources are limited in space and time (Kronfeld-Schor and Dayan 2003). In particular, floral resources in some plant species are distributed throughout a limited period of the day and the year for each plant species, providing a temporal overlap when requirements among floral visitors are similar (Polatto et al. 2014). Thus, the repertoire of bee activity patterns not only involves the collection of resources but also includes time spent building brood cells, supplying cells with

Corresponding author: G. Barônio, gudryan@gmail.com

Manuscript editor: Klaus Hartfelder collected resources, egg-laying, and closing brood cells (Stone et al. 1999). By performing these activities, bees change their behavior to optimize the time of resource collection during more appropriate environmental conditions (Stone et al. 1999; Teixeira et al. 2007). Bees tend to select specific periods to obtain a better performance in the distribution of these tasks during the day to maximize their efficiency (Ida and Kudo 2010; Schäffler and Dötterl 2011).

According to the degree of specialization within oil-collecting procedures, some bee tribes take advantage of others. One trait normally associated with better bee performance is body size, which allows a greater amount of resources to be transported with each visit (Biesmeijer and Richter 1999). Particularities related to morphological and behavioral differences between bee species exist, which limit the repertoire of available niches for bees. For example, Biesmeijer and Richter (1999) observed 
that bees have different color preferences for shaded and unshaded locations when foraging on the same plant, and concluded that some type of limitation exists in the temporal niche, according to the thermoregulation of these insects. In this case, Centridini and Tapinotaspidiini tribes are characterized by a differential body size and distinct morphological adaptations that facilitate the collection of floral resources from Malpighiaceae flowers, making these bees better adapted for resource collection. These adaptations include differentiated bristles distributed on three pairs of legs, which are responsible for the collection and transportation of oil resources (Vogel 1974; Simpson and Neff 1981; Coccuci et al. 2000).

In this context, floral resources provided over time to bees according to the sequential flowering periods of distinct species of Malpighiaceae (Vilela et al. 2014) are indispensable for the maintenance and survival of the oil-collecting guild, mainly the members of the tribes Centridini, Tapinotaspidiini, Tetrapediini, and Meliponini (Vogel 1974; Alves-dos-Santos et al. 2007). Centridini are large bees that normally land on flowers and touch the stigmas and stamens with the ventral region of the body, with the jaw stuck in the standard petal (Anderson 1979). These bees have a high performance in collecting Malpighiaceae floral oil due to these characteristics (Vogel 1988, 1990). Tapinotaspidiini bees show a higher diversification of morphological structures and adaptations to collect oil, such as patches of specialized setae on the fore and/or mid legs (Coccuci et al. 2000). Members of the Tetrapediini and Meliponini are small-sized and show distinct behavior. Compared to Centridini, these bees are small and used to rest on the back of the flower, encircling the cup and scraping elaiophores, or landing in front of the flower and collecting pollen directly from the anthers with or without contact with the stigmata (Vogel 1974; Sigrist and Sazima 2004; Cappellari et al. 2012).

To understand how oil-collecting bee activity is distributed throughout the day and whether it can be explained by different abilities, we used the intrinsic relationship of oil-collecting bees with Malpighiaceae flowers to evaluate the temporal niche overlap and to quantify the ability of visitors to collect floral resources on three species of
Malpighiaceae. We hypothesized that (I) there is an overlap between the temporal niche of visitors due to the similarities between their requirements in terms of floral resources and to the temporal limitation in the availability of those resources. We also hypothesized (II) that differences exist in the ability of the different oil-collecting tribes in gathering resources, followed by constraints that might limit the distribution of visits over time.

\section{MATERIALS AND METHODS}

\subsection{Study area and plant species}

Data were collected from March 2011 to January 2012 in the cerrado sensu stricto vegetation of the Ecological Reserve of Clube de Caça e Pesca Itororó de Uberlândia, Minas Gerais state, Brazil. The reserve is located at $48^{\circ} 17^{\prime} 45^{\prime \prime} \mathrm{O}$ and $18^{\circ} 58^{\prime} 56^{\prime \prime} \mathrm{S}$ WGS 84 , south of the urban center of the city of Uberlândia, with a mean elevation of $860 \mathrm{~m}$ and a natural area of about 640 ha. The vegetation of the reserve is composed of several savannah phytophysiognomies: vereda, campo limpo, campo sujo, campo cerrado, cerrado sensu stricto, and cerradão (see also Réu and Del-Claro 2005). The mean monthly rainfall ranges between 0 and $350 \mathrm{~mm}$, and the mean monthly temperature between 20.0 and $25.5{ }^{\circ} \mathrm{C}$ (data obtained from the Laboratory of Climatology and Water Resources, Federal University of Uberlândia).

The Malpighiaceae flora in the study area is composed at least by 15 different species, and the most abundant ones are Byrsonima intermedia, Banisteriopsis malifolia, Banisteriopsis campestris, Peixotoa tomentosa, and Heteropterys pteropetala (pers. observation). These most abundant species have sequential flowering, and although there is a small overlap between the end of one and beginning of the next one, the peaks of resource availability (flowers) are different (Alves-Silva 2010; Vilela et al. 2014).

The three shrub species studied from the Malpighiaceae family were $B$. campestris (A. Juss.) Little, which has pink flowers with a diameter between 2 and $3 \mathrm{~cm}$ each and B. malifolia (Nees \& Mart.) B. Gates, whose flower color ranges from intense pink to light pink, with flowers not being greater than $2.5 \mathrm{~cm}$ in diameter. Both species are distributed throughout much of the Brazilian territory (Mamede et al. 2014). The third species was $P$. tomentosa A. Juss., which is 
considered to be endemic in the state of Minas Gerais (Mamede et al. 2014) and possesses large flowers up to $3 \mathrm{~cm}$ in diameter, which are an intense yellow color. The three species possess sequential flowering periods, with a short or medium duration and a spatial overlap during the blooming phase from December to March for B. campestris, March to May for B. malifolia, and from June to September for $P$. tomentosa (Vilela et al. 2014). Although the species have different flowering periods, all of them have similar resource availability during anthesis: flowers open in the first hours of the morning while pollen is available quickly later. Floral oil availability is variable and in some cases can be collected by bees before anthesis when floral buds already exhibiting oil glands developed.

\subsection{Floral visitors}

Floral visitors were observed (one observer: GJB) between March 2011 and February 2012, even after the second week of each species flowering. The floral visitors of B. campestris (December to March), B. malifolia (March to June), and P. tomentosa (April to August) were assessed using the all-occurrence sample method (Altmann 1974), and all observed visitors were collected to identification. Each observation period consisted of 25 min of observation and 5-min intervals, from 07:00 to 17:00 h. A new plant was used for each observation period, totaling $27.5 \mathrm{~h}$ of observation per species. Thus, floral visitors were observed and collected in 22 non-consecutive periods in three nonconsecutive days. The following variables were measured during each observation period: (1) the total duration of the bee's visiting round at each plant and (2) the number of visited flowers per bush by each visitor. During the flower visits, we recorded hourly the temperature and humidity with a thermohygrometer datalogger HT500 Instrutherm®. Data concerning insolation, as a percentage of solar incidence each hour, were obtained from the Climatology and Water Resources Laboratory, in the Federal University of Uberlândia. The visitor collections were authorized by the license 27207-3 (Brazilian System of Biodiversity SISBIO - http://www.icmbio.gov.br/sisbio). All floral visitors observed were collected and identified based on entomological collections and specialized orientation of Ecology and Behaviour of Bees Laboratory (LECA-UFU) at the Federal University of Uberlândia and the Bees' Systematic Laboratory at Federal University of Minas Gerais (UFMG).

To know whether more than one peak was present in the frequency of visits during the observed period, the modality of the frequency of visits was tested via Hartigans test using the $\mathrm{R}$ package diptest. The differences between the main groups of visitors on each visit to the flower and the number of flowers visited per plant were tested using a non-parametric analysis of variance (Kruskal-Wallis), followed by a Dunn multiple comparison test. We classified the floral visits by tribe groups because all of them have similar size (our bee measures were as follows: Centridini $=1.62$ to $2.18 \mathrm{~cm}$; Meliponini $=0.38$ to $0.92 \mathrm{~cm}$; Tapinotaspidiini $=0.78$ to $1.15 \mathrm{~cm}$; and Tetrapediini $=1.02$ to $1.31 \mathrm{~cm}$ ) and behavior (Alves-dos-Santos et al. 2007). However, only the families of floral visitors with a high abundance were included in the statistical analyses, excluding members of the Halictidae and Syrphidae. To explore potential differences between the Malpighiaceae species fauna visitors, we standardized the data and calculated the dissimilarities between the three species using the Bray-Curtis index. These dissimilarities were represented in two dimensions using non-metric multidimensional scaling (NMDS) in the R software package Vegan. All graphs present the mean and standard error.

\subsection{Temporal niche overlap}

To evaluate the temporal niche overlap of floral visitors on three species of plants, we calculated the Pianka overlap index for each pair of species. The mean degree of community overlap was calculated using all possible pairs of species on the matrix of species (rows) and temporal niche (columns). To assess the significance of the means, the degree matrices were randomized $(n=10,000)$ according to the algorithms RA2, RA3, RA4 (Winemiller and Pianka 1990), and ROSARIO (Castro-Arellano et al. 2010) to create a null distribution of overlaps. The two-tailed significance was determined by comparing the values with respective empirical distribution $(\alpha=0.05)$. Temporal coincidence is indicated by an observed overlap that is significantly greater than that expected by chance. The observed segregation temporal overlap is indicated by a significantly lower value than that expected by chance (Albrecht and Gotelli 2001).

The randomizations and the significance of the models R2, R3, and R4 were generated using the 
software EcoSim 7.2 (Gotelli and Entsminger 2004). In the algorithm RA2, only the structure of the matrix is maintained. This is useful when we start from the premise that the absence of one resource in the observations should not also occur in randomizations. In RA3, only entries in each row of the matrix are randomly rearranged. This maintains the niche amplitude of the observed species, but allows the use of any of the possible states of resources. In RA4, only the non-zero entries in each row of the matrix of use are randomly shuffled. This procedure maintains the niche breadth of species and the pattern of zeros. Although the RA4 algorithm is conservative (Winemiller and Pianka 1990), it tends to produce a higher degree of expected niche overlap values within the data than other alternative algorithms. However, if the patterns are significant with RA4, they tend effectively to reality (see also Albrecht and Gotelli 2001). The randomizations and significance of ROSARIO model was conducted using the software TimeOverlap. In ROSARIO, each randomization of the entire activity pattern of species are advanced in sequence, and the alternative distributions represent the same activity with a new location in the time extent. This model is specific for temporal analysis because the autocorrelation is maintained according the continuous distribution of activity species patterns, and it seems biologically more realistic (Castro-Arellano et al. 2010).

\section{RESULTS}

We registered 98 visits from 31 floral visitor species: 28 species of bees and three species of flies. Among the bee species, 14 exhibited pollinator behavior, 11 acted as thieves, and three showed pollinator and thief behavior (Table I). The flies acted only as pollen robbers (Table I). The major number of visitor species was registered on B. campestris where we recorded 19 floral visitor species; in B. malifolia and P. tomentosa, we found 16 and 10 species, respectively (Fig. 1; Table I), and only three species visited all the three plant species. The frequency of visits showed a bimodal distribution of the three species $(B$. campestris $D=0.1, p=0.422$ / B. malifolia: $D=0.1, p=0.423 / P$. tomentosa: $D=0.05, p=0.999)$. The peaks of visits were not coincident with the periods during the day with higher temperatures (Fig. 2a, b). The insolation does not show peaks, only a decrease later 13:00 h (Fig. 2c).

The analysis of niche overlap based on null models suggests a higher mean overlap than that expected by chance in models RA2, RA3, RA4, and ROSARIO for B. campestris; in models RA3, RA4, and ROSARIO for B. malifolia; and in the RA3 and ROSARIO for P. tomentosa (Table II). Due to the limitations of the randomization procedure according to the requirements of model RA4, this model cannot be applied to $P$. tomentosa. From all possible pairs of visitor species of $B$. campestris, B. malifolia, and $P$. tomentosa, we found that $32.16,25.80$, and $83.33 \%$ showed a $\geq 50 \%$ similarity among their collection schedules, respectively.

The greatest visitor overlap included Paratrigona lineata, Tetrapedia curvitarsis, and Trigona spinipes, which were observed on all the three Malpighiaceae species (Table I). P. lineata acted only as a pollen robber. $T$. spinipes acted as an oil collector in the three plant species and a pollen robber in both Banisteriopsis species, and sporadically, it was able to promote the pollination of $B$. campestris during pollen collection. It collected pollen by moving and scraping all anthers and stigmata during a long time ( $2 \mathrm{~min})$. This is the first register about a Meliponini visitor with oil-collecting behavior. The behavior was characterized by $T$. spinipes turning around the calix, touching oil glands with proboscis and forelimbs, collecting and depositing the oil on corbiculae or abdomen. $T$. curvitarsis was an oil robber on the three plant species, a pollen robber in B. malifolia, and a potential pollinator of $B$. campestris during oil and pollen collection. T. curvitarsis and T. spinipes represented 17.4 and $10.2 \%$ (Table I), respectively, of the total sample. These two bee species performed long visits on B. campestris and collected pollen for approximately $2 \mathrm{~min}$; the bees landed on the flower, walked on the stamens and petals with their hind legs and medians, and scraped the stamens and stigmas with their forelegs.

The visiting patterns were very distinct between the bee tribes, with different durations of visiting rounds observed on $B$. campestris, $B$. malifolia, and $P$. tomentosa flowers ( $K=57.54 ; p<0.0001$; Fig. 3). The fastest flower 
Table I. Number of visits and collected resource of floral visits in Banisteriopsis campestris $(B C)$, B. malifolia $(\mathrm{Bm})$, and Peixotoa tomentosa $(\mathrm{Pt})$ in the cerrado sensu stricto in CCPIU in Uberlândia, MG, Brazil. (P)—pollen collect, (O) — oil collect, (OP) — oil and pollen collect. In collected resource, * indicates only robber behavior, ** indicates both robber and pollinator behavior, and the absence of symbols indicates only pollinator behavior.

\begin{tabular}{|c|c|c|c|c|c|c|c|c|}
\hline \multirow[t]{2}{*}{ Floral visitor } & \multirow[t]{2}{*}{ Tribe } & \multirow[t]{2}{*}{ Code } & \multicolumn{3}{|c|}{ Number of visits } & \multicolumn{3}{|c|}{ Collected resource } \\
\hline & & & $B c$ & $B m$ & $P t$ & $B m$ & $P t$ & $B c$ \\
\hline \multicolumn{9}{|l|}{ Apidae } \\
\hline Centris collaris & Centridini & 21 & - & 3 & 1 & - & $\mathrm{O} / \mathrm{P}$ & $\mathrm{O} / \mathrm{P}$ \\
\hline Centris dentata & Centridini & 26 & - & 1 & - & - & $\mathrm{O} / \mathrm{P}$ & - \\
\hline Centris dorsata & Centridini & 24 & - & 2 & 1 & - & $\mathrm{O} / \mathrm{P}$ & $\mathrm{O} / \mathrm{P}$ \\
\hline Centris fuscata & Centridini & 20 & - & 4 & 1 & - & $\mathrm{O} / \mathrm{P}$ & $\mathrm{O} / \mathrm{P}$ \\
\hline Centris machadoi & Centridini & 31 & - & - & 1 & - & - & $\mathrm{O} / \mathrm{P}$ \\
\hline Centris scopipes & Centridini & 22 & - & 3 & 1 & - & $\mathrm{O} / \mathrm{P}$ & $\mathrm{O} / \mathrm{P}$ \\
\hline Centris sponsa & Centridini & 25 & - & 1 & - & - & - & $\mathrm{O} / \mathrm{P}$ \\
\hline Centris varia & Centridini & 23 & - & 3 & - & - & $\mathrm{O} / \mathrm{P}$ & - \\
\hline Epicharis analis & Centridini & 13 & 3 & - & - & $\mathrm{O} / \mathrm{P}$ & - & - \\
\hline Epicharis bicolor & Centridini & 12 & 4 & - & - & $\mathrm{O} / \mathrm{P}$ & - & - \\
\hline Epicharis flava & Centridini & 11 & 4 & 3 & - & $\mathrm{O} / \mathrm{P}$ & $\mathrm{O} / \mathrm{P}$ & - \\
\hline Epicharis iheringi & Centridini & 14 & 1 & - & - & $\mathrm{O} / \mathrm{P}$ & - & - \\
\hline Paratrigona lineata & Meliponini & 16 & 2 & 1 & 1 & $\mathrm{P}^{*}$ & $\mathrm{P}^{*}$ & $\mathrm{P}^{*}$ \\
\hline Trigona spinipes & Meliponini & 2 & 7 & 1 & 2 & $\mathrm{O} *, \mathrm{O} / \mathrm{P}^{*}, \mathrm{P}^{* *}$ & $\mathrm{O} / \mathrm{P}^{*}$ & $\mathrm{O}^{*}$ \\
\hline Trigonisca sp. & Meliponini & 15 & 5 & - & - & $\mathrm{P}^{*}$ & - & - \\
\hline Lophopedia pygmaea & Tapinotaspidiini & 27 & - & 1 & - & - & $\mathrm{O} / \mathrm{P}$ & - \\
\hline Monoeca aff brasiliensis & Tapinotaspidiini & 4 & 2 & 1 & - & $\mathrm{O}^{*}$ & $\mathrm{O} / \mathrm{P}$ & - \\
\hline Monoeca $\mathrm{sp}$ & Tapinotaspidiini & 17 & 2 & 1 & - & $\mathrm{P}$ & $\mathrm{P}$ & - \\
\hline Paratetrapedia sp.1 & Tapinotaspidiini & 6 & 1 & - & - & $\mathrm{O}^{*}$ & - & - \\
\hline Paratetrapedia sp.2 & Tapinotaspidiini & 7 & 1 & - & - & $\mathrm{O}^{*}$ & - & - \\
\hline Tropidopedia carinata & Tapinotaspidiini & 9 & 1 & - & - & $\mathrm{O}^{*}$ & - & - \\
\hline Tropidopedia flavolineata & Tapinotaspidiini & 3 & 3 & - & 2 & $\mathrm{O}^{*}$ & - & $\mathrm{O}^{*}$ \\
\hline Tropidopedia nigrocarinata & Tapinotaspidiini & 10 & 1 & - & - & $\mathrm{O}^{*}$ & - & - \\
\hline Tropidopedia punctifrons & Tapinotaspidiini & 30 & - & - & 1 & - & - & $\mathrm{O}^{*}$ \\
\hline Tetrapedia curvitarsis & Tetrapediini & 1 & 16 & 1 & 1 & $\mathrm{O} *, \mathrm{O} / \mathrm{P}$ & $\mathrm{O} / \mathrm{P}^{*}$ & $\mathrm{O}^{*}$ \\
\hline Tetrapedia diversipes & Tetrapediini & 5 & 2 & - & - & $\mathrm{O}^{*}$ & - & - \\
\hline Tetrapedia sp. & Tetrapediini & 8 & 1 & - & - & $\mathrm{O}^{*}$ & - & - \\
\hline \multicolumn{9}{|l|}{ Halictidae } \\
\hline Dialictus sp. & Halictini & 18 & 1 & - & - & $\mathrm{P}^{*}$ & - & - \\
\hline \multicolumn{9}{|l|}{ Syrphidae } \\
\hline Argentinomyia sp. & Bacchini & 29 & - & 1 & - & - & $\mathrm{P}^{*}$ & - \\
\hline Xanthandrus sp. & Bacchini & 19 & 1 & - & - & $\mathrm{P}^{*}$ & - & - \\
\hline Pseudodoros sp. & Syrphini & 28 & - & 2 & - & - & $\mathrm{P}^{*}$ & - \\
\hline
\end{tabular}

visits observed in the three plant species were performed by members of the Centridini tribe $(1.67 \pm 0.1 \mathrm{~s}$ per flower), followed by those of the Tapinotaspidiini $(9.2 \pm 1.4 \mathrm{~s}$ per flower $)$, Tetrapediini (12.7 $\pm 2.42 \mathrm{~s}$ per flower), and Meliponini ( $24.37 \pm 5.4 \mathrm{~s}$ per flower). The 


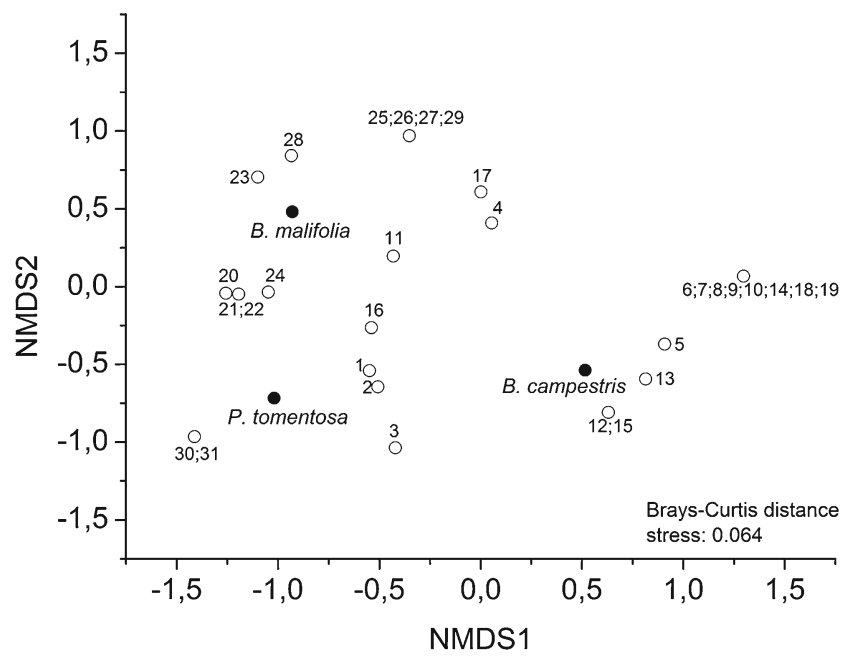

Figure 1. Non-metric multidimensional scaling of Malpighiaceae species visited (black dots) according to the species of floral visitors (white dots) following Bray-Curtis distance stress. The species are numbered according to Table I. Some points represent more than one species.

duration of the visits by members of these last three tribes did not differ statistically. However, the number of flowers visited per bush differed $(K=12.7 ; p=0.0054$; Fig. 3$)$ only between members of the Centridini $(2.41 \pm 0.3$ visited flowers per bush) and Meliponini (1.42 \pm 0.16 visited flowers per bush). The results for the other tribes were similar (Tapinotaspidiini: $1.71 \pm 0.51$ visited flowers per bush and Tetrapediini: $1.45 \pm 0.8$ visited flowers per bush).

\section{DISCUSSION}

The first hypothesis of our study was confirmed, showing that there is an overlap between the temporal niche of visitors due to similarities in their requirements in terms of floral resources and the temporal limitation in the availability of those resources. In fact, at least one-quarter of all possible pairs of species visiting the three Malpighiaceae species showed $\geq 50 \%$ similarity in time activity. The overlap in the temporal niche was more visible for $B$. campestris, which showed a higher richness of visitors and had an extremely significant temporal niche overlap by chance according to the conservative and realistic models: RA4 and ROSARIO. However, some morphophysiological limitations prevent resources from being collected at all times of the day (Biesmeijer and Richter 1999; Pereboom and Biesmeijer 2003). In a study about $700 \mathrm{~km}$ southwest of Uberlândia, using Bignoniaceae as species of study, the correlations of main pollinator species and climatic variables as lightness and temperature were low or medium (Almeida-Soares et al. 2010). Here, we observed that the visitors of these Malpighiaceae exhibited a bimodal distribution of visits throughout the day. These bimodal frequency distributions of visits represent a pattern that is probably related to abiotic factors such as temperature or humidity (Biesmeijer and Richter 1999; Stone et al. 1999) and do not allow a more discreet temporal niche overlap.

Although several species select the same periods in which to harvest floral resources (Santos and Presley 2010; Brito et al. 2012), the requirement for specific environmental conditions appears to be more important than interspecific interactions. We showed here that flower visitation to the Malpighiaceae between 11:00 and 13:00 h was clearly low or absent (see too Biesmeijer and Richter 1999; Boas et al. 2013). Almeida-Soares et al. (2010) observed the visits had unimodal pattern, distinct from the observed by us, but correlated to insolation. Furthermore, although our observed decrease in insolation seems weak, it appears to positively influence the oil-collecting bee visits. The decrease in insolation may offer a 


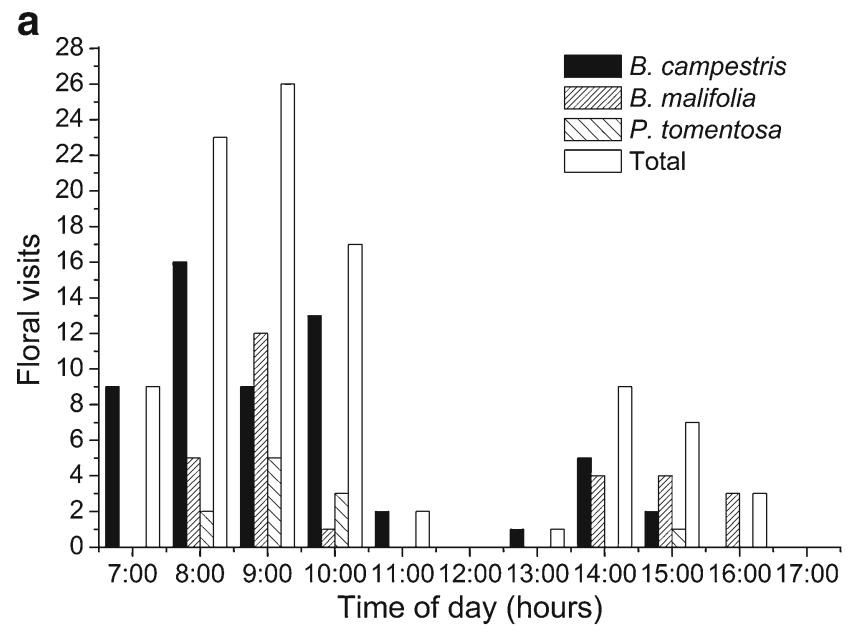

b $\circ$ B. campestris (January) - B. malifolia (April) \ P. tomentosa (July)
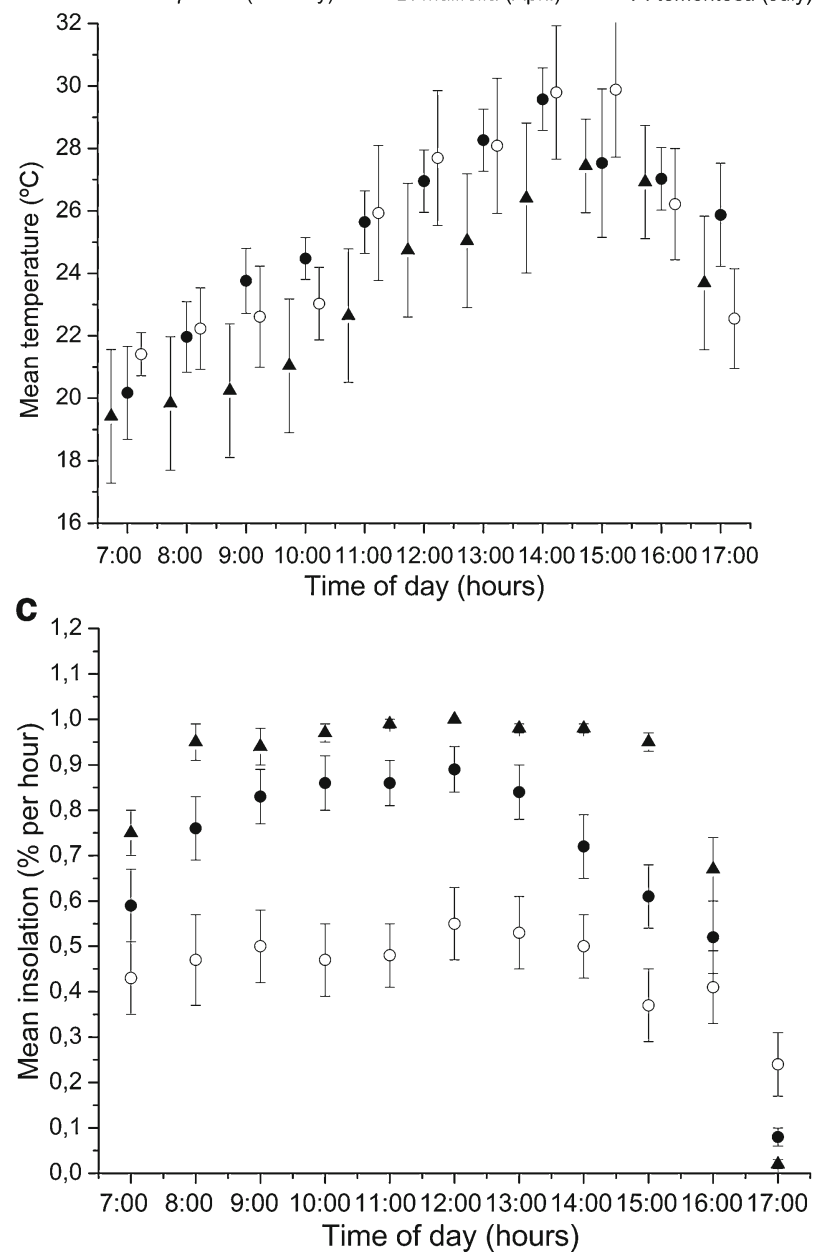

Figure 2. Floral visitation and climatic conditions. Frequency of visits to Banisteriopsis malifolia, B. campestris, and Peixotoa tomentosa, showing the bimodal pattern found for the three species (a); the variation pattern in temperature (b) and insolation (c) throughout the day. 
Table II. Results of the significance of the mean degree of temporal niche overlap between species visiting flowers of Banisteriopsis malifolia , B. campestris , and Peixotoa tomentosa according to the null models RA2, RA3, RA4, and ROSARIO. The $p$ values represent the significance of the niche overlap mean when it was higher than that expected by chance.

\begin{tabular}{llccc}
\hline Species & Models & Observed mean (Pianka index) & Simulated mean (Pianka index) & $p$ value \\
\hline B. malifolia & RA2 & 0.272 & 0.258 & 0.289 \\
& RA3 & 0.272 & 0.143 & 0.001 \\
& RA4 & 0.272 & 0.278 & 0.67 \\
& ROSARIO & 0.272 & 0.144 & $<0.001$ \\
B. campestris & RA2 & 0.368 & 0.305 & 0.006 \\
& RA3 & 0.368 & 0.174 & $<0.001$ \\
& RA4 & 0.368 & 0.325 & 0.008 \\
& ROSARIO & 0.368 & 0.187 & $<0.001$ \\
& RA2 & 0.244 & 0.255 & 0.5 \\
& RA3 & 0.244 & 0.11 & 0.022 \\
& RA4 & 0.244 & - & - \\
& ROSARIO & 0.244 & 0.124 & 0.021 \\
\hline
\end{tabular}

signal to good conditions to bee foraging (see Fig. 2a-c).

Comparing two Melipona costaricensis subspecies and two Cephalotrigona capitata color morphs, strong evidence was provided that body color can be involved in the regulation of body temperature (Pereboom and Biesmeijer 2003). According to this study, light bees take advantage of black bees and can collect resources for a greater length of time in conditions of solar exposure, due to a lower level of body heating. In another study, Biesmeijer and Richter (1999) demonstrated niche differentiation in two stingless bees according to body color. They observed that light bees $(M$. beecheii ) preferred sunny vegetation patches, whereas black bees (M. fasciata) preferred shady patches. In these two studies, the insolation was an important trait that can induce niche differentiation in bee species, in which fluctuations in microclimatic conditions can repel or be disadvantageous to certain visitors (Blüthgen and Klein 2011).

Activity time is an important niche dimension (Pianka 1974; Albrecht and Gotelli 2001; Brito et al. 2012). When competition for temporal availability of food among species of the same guild is strong, a temporal segregation in resource use can attenuate competition and facilitate coexistence
(Holldobler and Wilson 1990; Castro-Arellano et al. 2010). This factor creates an optimal equilibrium between the temporal overlap related to environmental conditions and resource requirements. However, we found a time overlap between all floral visitors, showing that floral visitors forage on plants when resources are available, but limited to the daily temporal gaps when environmental conditions are more suitable for each of them.

The difference on species visitation also can be explained by plant species competition with other plants which show phenological overlap (Waser 1978; Mitchell et al. 2009). The competition for pollination services can act as a selective force to establish and maintain an important evolutionary response: the sequential flowering between plant species (Waser 1978). In some cases, the sequential flowering phenomena is presented as an effective mutualism when, according flowering time, reproductive fitness of any peripheral species is modified by absence or reduction on floral attractiveness of central species (Waser and Real 1979). The Malpighiaceae plant species have sequential flowering on our study area, and it is an important characteristic to maintenance of all insect-plant interactions (Kaminski and Freitas 2010; but see Vilela et al. 2014). There are at least 15 

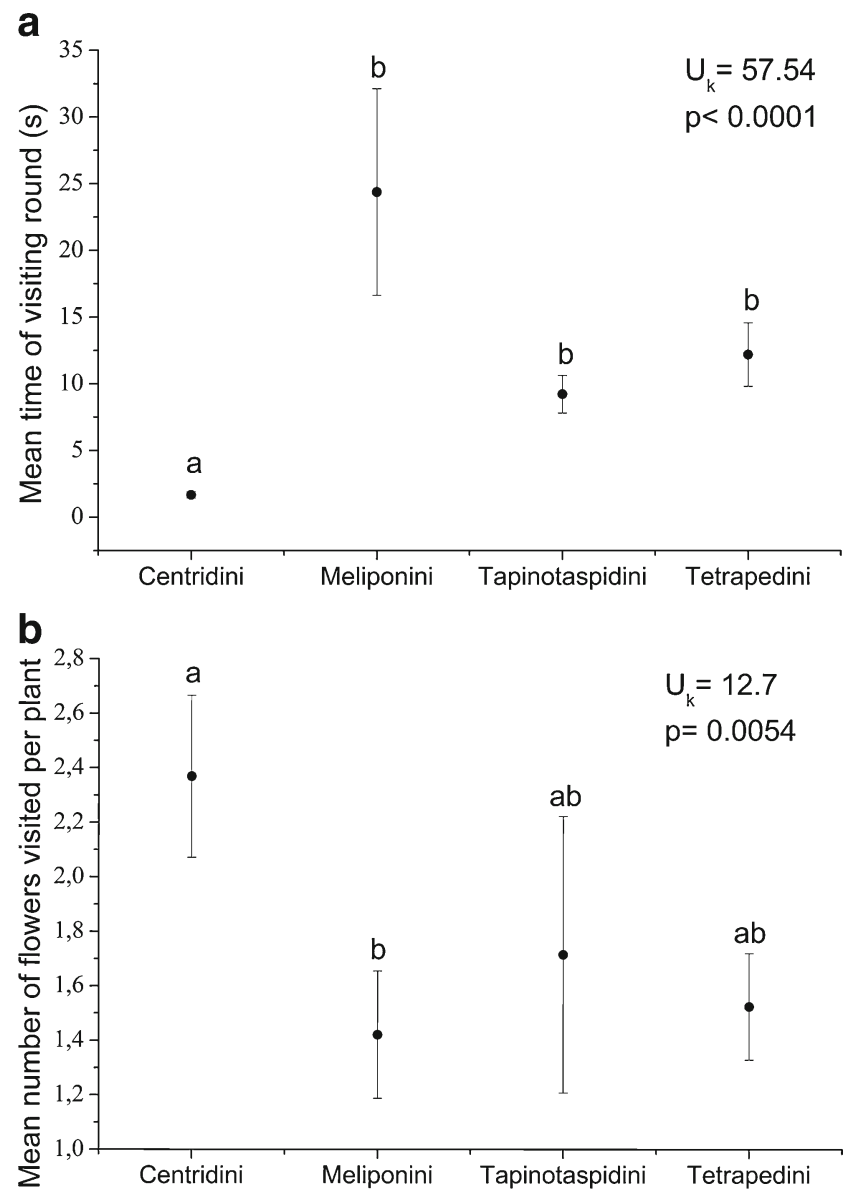

Figure 3. Mean time of visiting round (a) and mean number of flowers visited (b) by the major tribes of bees visiting the flowers of Banisteriopsis malifolia, B. campestris, and Peixotoa tomentosa.

Malpighiaceae species on study area with sequential flowering which offer floral resources through the year with short overlaps (Vilela et al. 2014).

Furthermore, although there is a brief overlap between flowering events on each two species, this sequential flowering of plant species promotes a seasonal availability of floral resources (e.g., floral oil) and becomes possible that all bee species have the oil source available in different seasons (Vilela et al. 2014). The sequential flowering may explain the different bee species visitation among the Malpighiaceae species. Hypothetically, we also believe that different reproductive seasons of bees and their respective need of floral resources for nesting can be responsible for the different of associated bee visitors in the Malpighiaceae species. The Epicharis bees were more active during B. campestris flowering, exactly on summer months (hot and wet season), when they used to show one generation by year with a diapause period (Alves-dos-Santos et al. 2007). Although there were eight Centris species which visited $B$. malifolia and P. tomentosa, but not B. campestris, both Epicharis analis and E. bicolor visited B. campestris but not the other two Malpighiaceae species. These differences in bee visitation may be affected by food preferences or by bee seasonality. Thereby, the Centridini bees can use their high collecting efficiency to collect the more abundant resources and minimize the collection on B. campestris .

We further observed a greater difference in bee efficiency in resource collecting, which corroborates our second hypothesis. This difference in 
resource harvesting was caused by the different efficiency levels of visitor species in gathering resources (Simpson and Neff 1981; Buchmann 1985; Coccuci et al. 2000). A higher efficiency of floral resource harvesting is defined by morphological and physiological characteristics of bees. For example, the size and robustness of the body allows resource collection in different climatic conditions and from distinct floral shapes and sizes (Quiroz-Garcia et al. 2001; Müller et al. 2006; Greenleaf et al. 2007). For example, $B$. campestris floral visitors take longer to obtain resources. The mean time of a single visit to B. campestris flowers $(13.89 \pm 3.2 \mathrm{~s}$ per flower) was largely determined by exclusive visitors, such as Tetrapediini, Meliponini, and Tapinotaspidiini bees, which perform longer visits than Centridini bees, due to different levels of efficiency in gathering resources (Simpson and Neff 1981; Buchmann 1985; Coccuci et al. 2000). Instead of $B$. campestris, the visiting rounds to $B$. malifolia and $P$. tomentosa flowers were shorter, due to the predominant visitation of larger Centridini bees that have a higher resource collection efficiency (Alves-dos-Santos et al. 2007; Gaglianone et al. 2010).

The high phenological proximity between B. malifolia and P. tomentosa in terms of their blooming (see more in Vilela et al. 2014) is capable of maintaining a higher floral visitor overlap between species. Even in this case, the differences observed in the composition of visitor guilds of each plant species were reflected in the reduced time spent in flower visitations. These two species predominantly received floral visitors with a higher harvesting efficiency, such as Centridini bees. This tribe, which is dominated by individuals with a relatively large body, is classified as one of the leading Malpighiaceae pollinators (Vogel 1988; Alves-dos-Santos et al. 2007; Boas et al. 2013), and in this study, they visited a larger number of flowers per plant in the shortest time period. This is important for cross-pollination, due to the high mobility of bees between different shrubs and is associated with a high resource collection efficiency (Buchmann 1985; Vogel 1990; Bezerra et al. 2009).

The ability of Centridini bees is easily distinguished from that of other bees due to their larger body size and consequent ease of embracing the flower while scraping the elaiphores below (Vogel 1974, 1988; Alves-dos-Santos et al. 2007). These differences are visible between bees which visit B. campestris, where we observed four Epicharis (Centridini) species visiting with high efficiency while the smaller bees visited spending more time. Although indirect, the efficiency of visitors in gathering floral resources reflects their efficiency as pollinators of the Malpighiaceae (Vogel 1974, 1990; Sigrist and Sazima 2004; Mello et al. 2013). Specifically, in this case, when plants have extrafloral nectaries and attract ants, the reduced time spent during Malpighiaceae flower visits can be useful for both plant and pollinator. A recent study by Assunção et al. (2014) showed that pollinators of a common Cerrado Malpighiaceae species, Heteropterys pteropetala A. Juss, can recognize ants on flowers and avoid these flowers. Although the visitation by larger bees is decreased when ants are associated with flowers (Cembrowski et al. 2014), the association between the short amount of time spent in visiting a Malpighiaceae flower and the large and strong body of the Centridini bees possibly cause these bees to be less susceptible to predators than smaller bees (Assunção et al. 2014).

The pollination efficiency is probably greater for large bees, because they have a greater strength and body size and can therefore break open the cuticular layer of the stigmata, which moistens the stigma surface and favors pollen fixation from the ventral portion of the bee's body (Vogel 1974; Alves-dos-Santos et al. 2007). In contrast, although some small- and medium-sized bees (e.g., Tapinotaspidiini) also have special adaptations for collecting floral resources, such as oil from the Malpighiaceae (Coccuci et al. 2000; Aguiar and Melo 2011), their body size does not lead to a pollination effectiveness as high as that observed for Centridini bees. These morphological differences can occur in certain Centridini species that are slimmer and have a smaller body area for the deposition of pollen. However, they have the same ability to vibrate and involve all anthers during the flower visit (Buchmann 1985; Vogel 1988; Alves-dos-Santos et al. 2007). 
The Tapinotaspidiini, Tetrapediini, and Meliponini are smaller bees (Simpson and Neff 1981; Buchmann 1985; Coccuci et al. 2000; Cappellari et al. 2012) and have a longer visitation time and visit fewer flowers per time interval; therefore, their collecting behavior is considered to be less efficient for promoting pollination compared to that of the Centridini bees. Among floral visitors that exhibited distinct behavior, we can name $P$. lineata and $T$. spinipes. $P$. lineata only showed pollen thief behavior in all the three plant species, collecting pollen only from older flowers (second-day flowers). Therefore, the flowers had probably already been visited and pollinated by larger bees and only contained residual pollen, as observed by Anderson (1979). Therefore, the collecting activity of $P$. lineata might indirectly decrease the production of fruits by damaging floral parts near the anthers, such as the stigma or the style. Pollen collection from $P$. lineata is probably influenced by small differences in the collection efficiency of previous visitors (Simpson and Neff 1981; Alves-dos-Santos et al. 2007).

The smaller bees $T$. curvitarsis and $T$. spinipes showed a relatively higher visitation in B. campestris visits and also exhibited consistent pollination behavior. T. spinipes exhibited both behaviors of robber and pollinator. Although we registered the oil collection by $T$. spinipes, the Meliponini bees are not considered on literature as an oilcollecting bee by lacking of morphological specific structures to collect this resource, and due oil is not essential for its nesting (Vogel 1974; Buchmann 1987; Alves-dos-Santos et al. 2007). However, it was a curious observation, because $T$. spinipes also was observed collecting pollen with a consistent pollinator behavior in Malpighiaceae species. Considering that this as an appropriate visit for pollination and the duration of visits, there is support for the idea that small bee species can rarely act as pollinators of medium- or large-size flowers of the Malpighiaceae; this was corroborating with Vogel assumption that small bee can pollinate small flowers (Vogel 1990; see also Sigrist and Sazima 2004).

In summary, we observed that oil-collecting bees have a significant temporal niche overlap associated with the bimodal distribution of the frequency of visitation in the three Malpighiaceae species. The floral visitors exhibited a higher niche overlap than expected, confirming our first hypothesis. The higher temporal overlap of floral visitor foraging activities appears to be adapted to the environmental conditions. Furthermore, corroborating to our second hypothesis, we observed that floral visitors showed different efficiencies in resource collection, due to the distinct oil-collecting skills of some bee tribes. Compared to the other tribes, Centridini bees have a higher efficiency in harvesting resources than other oil-collecting bees. This higher efficiency allows Centridini bees to collect resources faster and to make a legitimate visit according to the specific requirements of Malpighiaceae flowers.

\section{ACKNOWLEDGMENTS}

The first author, GJB, acknowledges the funding agency Coordenação de Aperfeiçoamento de Pessoal de Nível Superior for the scholarship granted from March 2011 until April 2013. The second author, HMTS, acknowledges Conselho Nacional de Desenvolvimento Científico e Tecnológico for the financial support. The authors thank Fernando Amaral da Silveira, José Eustáquio dos Santos Júnior, Antonio José Camilo de Aguiar, Solange Cristina Augusto, and Laice Souza Rabelo for their valuable help with bee identification. The authors also thank Dr. André Rodrigo Rech and two anonymous reviewers for manuscript comments and relevant suggestions.

Chevauchement temporel des niches écologiques et capacité différente des abeilles dans la récolte des ressources florales sur trois espèces de Malpighiaceae du Brésil.

Centridini/conditions environnementales/abeilles récolteuses d'huile/efficacité pollinisatrice/floraison séquentielle

Zeitliche Überlappung der ökologischen Nischen und unterschiedliche Fähigkeit von Bienen, die floralen Resourcen von drei Arten brasilianischer Malpighiaceen zu nutzen

Centridini/Umweltbedingungen/ölsammelnde Bienen/ Bestäubereffizienz/Blütenabfolge 


\section{REFERENCES}

Aguiar, A.J.C., Melo, G.A.R. (2011) Revision and phylogeny of the bee genus Paratetrapedia Moure, with description of a new genus from the Andean Cordillera (Hymenoptera, Apidae, Tapinotaspidini). Zool. J. Linnean Soc. 162, 351-442

Albrecht, M., Gotelli, N.J. (2001) Spatial and temporal niche partitioning in grassland ants. Oecologia 126, 134-141

Almeida-Soares, S., Polatto, L.P., Dutra, J.C.S., TorezanSilingardi, H.M. (2010) Pollination of Adenocalymma bracteatum (Bignoniaceae): Floral Biology and Visitors. Neotrop. Entomol. 39, 941-948

Alves-dos-Santos, I., Machado, I.C., Gaglianone, M.C. (2007) História natural das abelhas coletoras de óleo. Oecologia Bras. 11, 554-557

Alves-Silva, E. (2010) A importância da floração seqüencial de Malpighiaceae para a manutenção da diversidade de tripés (Thysanoptera) no cerrado. Master thesis, 73p. Programa de Pós Graduação em Ecologia e Conservação de Recursos Naturais, Universidade Federal de Uberlândia

Anderson, W.R. (1979) Floral Conservatism in Neotropical Malpighiaceae. Biotropica 11, 219

Assunção, M. A, Torezan-Silingardi, H.M., Del-Claro, K. (2014) Do ant visitors to extrafloral nectaries of plants repel pollinators and cause an indirect cost of mutualism? Flora: Morphol Distrib Funct Ecol Plants 209, 244-249

Bezerra, E.L.S., Machado, I.C., Mello, M. A. R. (2009) Pollination networks of oil-flowers: A tiny world within the smallest of all worlds. J. Anim. Ecol. 78, 10961101

Biesmeijer, J.C., Richter, J.A.P. (1999) Niche differentiation in nectar-collecting stingless bees: the influence of morphology, oral choice and interference competition. Ecol Entomol 24, 380-388

Blüthgen, N., Klein, A.M.M. (2011) Functional complementarity and specialisation: The role of biodiversity in plant-pollinator interactions. Basic Appl Ecol. 12, 282-291

Boas, J.C.V., Fava, W.S., Laroca, S., Sigrist, M.R. (2013) Two sympatric Byrsonima species (Malpighiaceae) differ in phenological and reproductive patterns. Flora: Morphol Distrib Funct Ecol Plants 208, 360-369

Brito, A.F.F., Presley, S.J.J., Santos, G.M. (2012) Temporal and trophic niche overlap in a guild of flower-visiting ants in a seasonal semi-arid tropical environment. J Arid Environ 87, 161-167

Buchmann, S.L. (1985) Bees use vibration to aid pollen collection from non-poricidal flowers. J Kansas Entomol Soc 8, 517-525

Buchmann, S.L. (1987) The ecology of oil flowers and their bees. Annu. Rev. Ecol. Syst. 18, 343-369

Cappellari, S.C., Melo, G.A.R., Aguiar, A.J.C., Neff, J.L. (2012) Floral oil collection by male Tetrapedia bees
(Hymenoptera: Apidae: Tetrapedini). Apidologie 43, 39-50

Castro-Arellano, I., Lacher, T.E., Willig, M.R., Rangel, T.F. (2010) Assessment of assemblage-wide temporal niche segregation using null models. Methods Ecol Evol 1, 311-318

Cembrowski, A.R., Tan, M.G., Thomson, J.D., Frederickson, M.E. (2014) Ants and ant scent reduce bumblebee pollination of artificial flowers. Am. Nat. 183, 133-9

Coccuci, A.A., Séric, A., Roig-Alsina, A. (2000) Oilcollecting structures in Tapinotaspidini: their diversity, function and probable origin. Mitt. Münch. Entomolog. Ges. 90, 51-74

Gaglianone, M.C., Rocha, H.H.S., Benevides, C.R., Junqueira, C.N., Augusto, S.C. (2010) Importância De Centridini (Apidae) Na Polinização De Plantas De Interesse Agrícola: O Maracujá-Doce (Passiflora Alata Curtis ) Como Estudo De Caso Na Região Sudeste Do Brasil. Oecologia Aust. 14, 152-164

Gotelli, N.J., Entsminger, G.L. (2004) EcoSim: Null models software for ecology. Version 7

Greenleaf, S.S., Williams, N.M., Winfree, R., Kremen, C. (2007) Bee foraging ranges and their relationship to body size. Oecologia, 153, 589-96

Holldobler, B., Wilson, E.O. (1990) The ants. Harvardh University Press, Cambridge.

Ida, T.Y., Kudo, G. (2010) Modification of bumblebee behavior by floral color change and implications for pollen transfer in Weigela middendorffiana. Evol. Ecol. 24, 671-684

Kaminski, L.A., Freitas, A.V.L. (2010) Natural history and morphology of immature stages of the butterfly Allosmaitia strophius (Godart) (Lepidoptera: Lycaenidae) on flower buds of Malpighiaceae. Stud. Neotropical Fauna Environ. 45, 11-19

Kronfeld-Schor, N., Dayan, T. (2003) Partitioning of time as an ecological resource. Annu. Rev. Ecol.Syst. 34, 153-181

Mamede, M.C.H., Amorim, A.M., Sebastiani, R. (2014) Malpighiaceae: Lista de Espécies da Flora do Brasil URL http://floradobrasil.jbrj.gov.br/jabot/ floradobrasil/FB155 [accessed on 2014]

Mello, M. a. R., Bezerra, E.L.S., Machado, I.C. (2013) Functional Roles of Centridini Oil Bees and Malpighiaceae Oil Flowers in Biome-wide Pollination Networks. Biotropica 45, 45-53

Mitchell, R.J., Irwin, R.E., Flanagan, R.J., Karron, J.D. (2009) Ecology and evolution of plant-pollinator interactions. Ann. Bot. 103, 1355-63

Müller, A., Diener, S., Schnyder, S., Stutz, K., Sedivy, C., Dorn, S. (2006) Quantitative pollen requirements of solitary bees: Implications for bee conservation and the evolution of bee-flower relationships. Biol. Conserv. $130,604-615$

Pereboom, J.J.M., Biesmeijer, J.C. (2003) Thermal constraints for stingless bee foragers: the importance of body size and coloration. Oecologia 137, 42-50 
Pianka, E.R. (1974) Niche overlap and diffuse competition. Proc. Natl. Acad. Sci. 71, 2141-2145

Polatto, L.P., Chaud-Netto, J., Alves-Junior, V. V. (2014) Influence of Abiotic Factors and Floral Resource Availability on Daily Foraging Activity of Bees: Influence of Abiotic and Biotic Factors on Bees. J. Insect Behav. 27, 593-612

Quiroz-Garcia, D.L., Martinez-Hernandez, E., PalaciosChavez, R., Galindo-Miranda, N.E. (2001) Nest provisions and pollen foraging in three species of solitary bees (Hymenoptera : Apidae) from Jalisco, Mexico. J. Kansas Entomol. Soc. 74, 61-69

Réu, W.F., Del-Claro, K. (2005) Natural history and biology of Chlamisus minax Lacordaire (Chrysomelidae: Chlamisinae). Neot. Entomol. 34, 357-362.

Santos, G.M.M., Carvalho, C.A.L., Aguiar, C.M.L., Macêdo, L.S.S.R., Mello, A.R. (2013) Overlap in trophic and temporal niches in the flower-visiting bee guild (Hymenoptera, Apoidea) of a tropical dry forest. Apidologie 44, 64-74

Santos, G.M.M., Presley, S.J. (2010) Niche overlap and temporal activity of social wasps (Hymenoptera: Vespidae) in a Brazilian cashew orchard. Sociobiology $56,121-131$

Schäffler, I., Dötterl, S. (2011) A day in the life of an oil bee: Phenology, nesting, and foraging behavior. Apidologie 42, 409-424

Sigrist, M.R., Sazima, M. (2004) Pollination and reproductive biology of twelve species of neotropical Malpighiaceae: Stigma morphology and its implications for the breeding system. Ann. Bot. 94, 33-41
Simpson, B.B., Neff, J.L. (1981) Floral reward: Alternatives to pollen and nectar. Ann. Mo. Bot. Gard.. 69, $301-322$

Stone, G.N., Gilbert, F., Willmer, P., Potts, S., Semida, F., Zalat, S. (1999) Windows of opportunity and the temporal structuring of foraging activity in a desert solitary bee. Ecol. Entomol. 24, 208-221

Teixeira, A.F.R., Oliveira, F.F., Viana, B.F. (2007) Utilization of floral resources by bees of the genus Frieseomelitta von ihering (Hymenoptera: Apidae). Neotropic. Entomol. 36, 675-684

Vilela, A.A., Torezan-Silingardi, H.M., Del-Claro, K. (2014) Conditional outcomes in ant-plant-herbivore interactions influenced by sequential flowering. Flora (Jena) 209, 359-366

Vogel, S. (1974) Olblumen und olsammelnde Bienen. Tropische und Subtropische Pflanzenwelt 7, 285-547

Vogel, S. (1988) The oil-bee oil-flower relationships parallelism and other aspects of their evolution in space and time. Z. Zool. Syst. Evol.forsch. 26, 341-362

Vogel, S. (1990) History of the Malpighiaceae in the light of pollination ecology. Mem. N. Y. Bot. Gard. 55, 130-142

Waser, N.M. (1978) Competition for Hummingbird Pollination and Sequential Flowering in Two Colorado Wildflowers. Ecology 59, 934

Waser, N.M., Real, L.A. (1979) Effective mutualism between sequentially flowering plant species. Nature $281,670-672$

Winemiller, K., Pianka, E.R. (1990) Organization in natural assemblages of desert lizards and tropical fishes. Ecol. Monogr. 60, 27-55 